\title{
PENGARUH KEMUDAHAN DAN PELAYANAN TERHADAP KEPATUHAN WAJIB PAJAK DALAM MEMBAYAR PAJAK PENGHASILAN ORANG PRIBADI ( Studi di Kantor Pelayanan Pajak Pratama Bantul )
}

\author{
Dwi Woro Setiyoningrum \\ Program Studi Akuntansi, Fakultas Ekonomi \\ Universitas Sarjanawiyata Tamansiswa Yogyakarta \\ arumgratia@gmail.com
}

\begin{abstract}
This study discusses the influence of convenience and service to the taxpayer compliance in paying income tax. This study was performed at the Tax Office Primary Bantul. The purpose of this research is to determine whether the facilities and services affect taxpayer compliance and what efforts Bantul Pratama Tax Office in improving tax compliance.

This study is built with two hypotheses, namely: (1) ease in the processoftaxation, (2) positive effect Compliance Services The type of data in this study is primary data, with sampling at Bantul Pratama Tax Office using incidental sampling technique. Questionnaires were used as a sample of 100 and only return 90. This research is kualtitatif, and testing using multiple linear regression statistical tests.

The results of this study indicate that two simultaneous independent variables significantly influence adherence. Partially shown that convenience has a positive and significant effect on adherence. While the service has a positive effect but not significant effect on compliance.
\end{abstract}

\section{Keywords : Taxpayer Compliance, Convenience in Paying tax, Service tax}

\section{Pendahuluan}

Untuk

menjalankan

fungsi

pemerintahan dan pembangunan, pemerintah memerlukan dana yang tidak sedikit, sedangkan penerimaan negara dari devisa yang berasal dari ekspor dan berbagai jenis bantuan dari luar negeri masih dirasa tidak cukup jika dibanding dengan besarnya pengeluaran untuk membiayai kegiatan pemerintahan dan pembangunan dimaksud. Pemerintah semakin dituntut untuk mampu menggali sumber-sumber dana lain, khusu snya sumber-sumber dana yang berasal dari kemampuan bangsa sendiri baik berupa hasil kekayaan alam maupun dari iuran masyarakat (pajak) sebagai wujud kemandirian bangsa dalam membiayai kegiatan pemerintahan dan pembangunan (Prasetyawati,2012) .
Upaya menjalankan fungsi pemerintah dan pembangunan dalam mewujudkan tujuan tersebut salah satunya dengan pembangunan. Pembangunan nasional adalah kegiatan yang berlangsung terus-menerus dan berkesinambungan yang bertujuan untuk meningkatkan kesejahteraan rakyat. Dalam melaksanakan pembangunan nasional masalah pembiayaan menjadi sangat vital. Pembiayaan pembangunan ini direalisasikan ke dalam Anggaran Pendapatan dan Belanja Negara (APBN) (Prasetyawati,2012)

Kantor Pelayanan Pajak Pratama Bantul mengalami peningkatan jumlah wajib pajak orang pribadi yang terdaftar dan wajib pajak efektif pada empat tahun terakhir, dari tahun 2009 sampai tahun 2012. Wajib pajak efektif adalah wajib pajak yang masih aktif dalam membayar pajaknya. Data mengenai jumlah wajib pajak orang pribadi terdaftar 
efektif di Kantor Pelayanan Pajak (KPP) berikut ini:

Pratama Bantul dapat dilihat dalam tabel 1

Tabel 1

Jumlah Wajib Pajak Orang Pribadi Yang Terdaftar Efektif di Kantor Pelayanan Pajak Pratama Bantul

\begin{tabular}{cccc}
\hline Tahun & $\begin{array}{c}\text { Wajib Pajak } \\
\text { Orang Pribadi } \\
\text { Terdaftar }\end{array}$ & $\begin{array}{c}\text { Wajib Pajak Orang Pribadi } \\
\text { yang menyampaikan SPT } \\
\text { Tahunan }\end{array}$ & $\begin{array}{c}\text { Tingkat Kepatuhan } \\
\text { Wajib Pajak Orang } \\
\text { Pribadi }\end{array}$ \\
\hline 2009 & 38434 & 27902 & $72,60 \%$ \\
2010 & 57691 & 40547 & $70,28 \%$ \\
2011 & 65491 & 41695 & $63,67 \%$ \\
2012 & 67472 & 48197 & $71,43 \%$ \\
\hline
\end{tabular}

Sumber : Seksi Pengolahan Data dan Informasi Kantor Pelayanan Pajak Pratama Bantul

Tingkat kepatuhan di Kantor Pelayanan Pajak Pratama Bantul pada tahun 2009 sebesar 72,60\%, pada tahun 2010 tingkat kepatuhan menurun menjadi 70,28\%, tahun 2011 tingkat kepatuhan menurun menjadi 63,67\% dan tahun 2012 tingkat kepatuhan naik menjadi 71,43\%. Agar terjadi kenaikan terus menerus, maka perlu dilakukan kajian mengenai faktor-faktor apa saja yang mempengaruhi wajib pajak dalam malaksanakan kewajiban pajak, guna meningkatkan kepatuhan wajib pajak yang terdaftar di Kantor Pelayanan Pajak Pratama Bantul.

\section{Metode Penelitian}

Sifat yang digunakan dalam penelitian ini adalah deskriptif kualitatif. Metode analisis deskriptif kualitatif yaitu, merupakan tata cara penelitian yang menghasilkan data yang menghasilkan diskriptif . Analisis deskriptif harus dimulai sejak awal penelitian, data yang diperoleh dari lapangan harus segera dituangkan ke dalam bentuk tulisan dan analisis.

Tempat Penelitian dilakukan di Kantor Pelayanan Pajak Pratama Bantul di Jalan Urip Sumoharjo No. 7 Gose Bantul.

Waktu Penelitian Pelaksanaan penelitian dilaksanakan pada bulan Oktober 2012 sampai dengan Februari 2013.

Penelitian ini terdiri atas satu variabel dependen dan dua variabel Independen. (1) Variabel dependen yaitu merupakan variabel yang dipengaruhi oleh variabel lain. Variabel dependen dalam penelitian ini adalah kepatuhan wajib pajak orang pribadi. (2)Variabel independen merupakan variabel yang mempengaruhi atau menjadi sebab perubahan lain. Variabel independen dalam penelitian ini adalah kemudahan dan pelayanan proses perpajakan di Kantor Pelayanan Pajak Pratama Bantul.

Populasi mengacu pada keseluruhan kelompok orang, kejadian, atau hal minat yang ingin diinvestigasi (Fikriningrum, 2012). Populasi yang digunakan dalam penelitian ini adalah wajib pajak orang pribadi yang terdaftar di Kantor Pelayanan Pajak Pratama Bantul dan masih tergolong wajib pajak efektif. Alasan pemilihan populasi ini karena wajib pajak orang pribadi efektif merupakan wajib pajak yang memenuhi kewajiban perpajakannya, dan penelitian ini berfokus terhadap faktor-faktor yang mempengaruhi wajib pajak orang pribadi dalam memenuhi kewajiban perpajakannya.

Teknik pengambilan sampel dalam penelitian ini adalah teknik incidental sampling. Teknik incidental sampling adalah teknik penentuan sampel berdasarkan kebetulan yaitu siapa saja yang secara kebetulan bertemu dengan peneliti dapat digunakan sebagai sampel, apabila orang yang kebetulan ditemui cocok sebagai sumber data (Fikriningrum, 2012). Alasan pemilihan teknik pengambilan sampel ini 
adalah untuk mempermudah proses pengambilan sampel. Penentuan jumlah sampel penelitian berdasarkan pada pernyataan Roscoe (1975) dalam Fikriningrum (2012) yang menyatakan bahwa jumlah sampel yang memadai untuk penelitian adalah berkisar antara 30 hingga 500.

Sumber data yang digunakan dalam penelitian ini adalah data primer. Data yang diperoleh dari sumber asli dan dikumpulkan secara khusus (Rindi 2012: 4). Data primer yang diperoleh dari pengumpulan data dengan menggunakan metode survei menggunakan media kuesioner. Untuk mengukur pendapat responden digunakan skala Likert lima angka yaitu mulai angka 5 untuk pendapat sangat setuju (SS) dan angka 1 untuk sangat tidak setuju (STS).

Penelitian ini menggunakan beberapa metode pengumpulan data (a) Metode study pustaka Studi kepustakaan adalah segala usaha yang dilakukan oleh peneliti untuk menghimpun informasi yang relevan dengan topik atau masalah yang akan atau sedang diteliti. Informasi itu dapat diperoleh dari buku-buku ilmiah, laporan penelitian, karangan-karangan ilmiah, tesis dan disertasi, peraturan-peraturan, ketetapanketetapan, buku tahunan, ensiklopedia, dan sumber-sumber tertulis baik tercetak maupun elektronik lain. (Rindi, 2012: 4), (b) Metode Dokumentasi Menurut Rindi (2012:4) metode dokumentasi ini merupakan teknik pengumpulan data dengan menggunakan cara mengamati, melihat dan mengumpulkan dokumen-dokumen serta catatan-catatan yang ada baik berupa tulisan maupun gambar maupun keterangan lain yang dilakukan di Kantor Pelayanan Pajak (KPP) Pratama Bantul. (c) Metode kuesioner adalah daftar pernyataan tertulis yang telah dirumuskan sebelumnya yang akan dijawab responden. Dalam metode ini teknik pengumpulan data dengan menggunakan pengajuaan daftar pernyataan tertulis yaitu tentang kepatuhan wajib pajak orang pribadi

.Uji Kualitas Data 1. Validitas Valid tidaknya suatu item dapat diketahui dengan membandingkan indek korelasi product moment ( $r$ hitung) dengan nilai kristisnya( Budi). 2. Reliabilitas Menurut Singarimbun dan Effendi (1989) dalam Budi, Reabilitas adalah indek yang menunjukan sejauh mana suatu alat ukur dapat dipercaya atau dapat diandalkan. Suatu kuesioner dikatakan realibel atau handal jika jawaban seseorang terhadap pernyataan adalah konsisten atau stabil dari waktu ke waktu.

Analisis data digunakan untuk menyederhanakan data agar data lebih mudah diinterpretasikan. Analisis ini dilakukan dengan menggunakan teknik analisis regresi berganda untuk mengolah dan membahas data yang telah diperoleh dan untuk menguji hipotesis yang diajukan. Teknik analisis regresi berganda dipilih untuk digunakan pada penelitian ini karena teknik regresi berganda dapat menyimpulkan secara langsung mengenai pengaruh masingmasing variabel bebas yang digunakan secara parsial ataupun secara bersama-sama.

Persamaan regresi yang dirumuskan berdasarkan hipotesis yang dikembangkan adalah sebagai berikut:

$$
\mathrm{Y}=\mathrm{a}+\mathrm{b} 1 \mathrm{X} 1+\mathrm{b} 2 \mathrm{X} 2+\mathrm{e}
$$

Keterangan:

$\mathrm{Y}=$ Kepatuhan wajib pajak orang pribadi

a $=$ Konstanta

b1 = Koefisien regresi variabel kemudahan proses perpajakan

b2 = Koefisien regresi variabel pelayanan pajak

$\mathrm{X} 1=$ Kemudahan proses perpajakan

$\mathrm{X} 2$ = Pelayanan pajak

e $=$ Error

Uji asumsi klasik yang digunakan meliputi uji normalitas, uji multikolonieritas, dan uji heteroskedastisitas

\section{a. Normalitas}

Uji Normalitas bertujuan untuk menguji apakah dalam model regresi, variabel pengganggu atau residual memiliki distribusi normal atau tidak (Ghozali, 2006). Model regresi yang baik adalah memiliki data yang terdistribusi normal. Ada dua cara untuk mendeteksi apakah residual 
berdistribusi normal atau tidak yaitu dengan analisis grafik atau uji statistik. (Ghozali, 2006).

Apabila menggunakan grafik, normalitas umumnya dideteksi dengan melihat tabel histogram. Namun demikian, dengan hanya melihat tabel histogram bisa menyesatkan, khususnya untuk jumlah sampel yang kecil. Dasar pengambilan dengan menggunakan normal probability plot adalah sebagai berikut: (Ghozali, 2005).

1) Jika data menyebar di sekitar garis diagonal dan mengikuti arah garis diagonal atau grafik histogramnya menunjukkan pola distribusi normal, maka model regresi memenuhi asumsi normalitas.

2) Jika data menyebar jauh dari garis diagonal dan/atau tidak mengikuti arah garis diagonal atau garis histogram tidak menunjukkan pola distribusi normal, maka model regresi tidak memenuhi asumsi normalitas.

\section{b. Multikolinearis}

Pengujian asumsi kedua adalah uji multikolinearitas (multicollinearity) antar variabel-variabel independen yang masuk ke dalam model. Metode untuk mendiagnosa adanya multicollinearity dilakukan dengan uji Varience Inflation Factor (VIF) yang dihitung dengan rumus sebagai berikut:

$$
\mathrm{VIF}=1 / \text { Tolerance }
$$

Jika VIF lebih besar dari 10, maka antar variabel bebas (independent variable) terjadi persoalan multikolinearitas (Gujarati, 1993).

\section{c. Uji Heteroskedastisitas}

Pengujian asumsi ketiga adalah heteroskedastisitas (heteroscedasticity) digunakan untuk mengetahui ada tidaknya heteroskedastisitas, dalam hal ini akan dilakukan dengan cara melihat grafik Scatterplot. Jika dalam grafik terlihat ada pola tertentu seperti titik-titik yang ada membentuk pola tertentu yang teratur (bergelombang, melebar, kemudian menyempit), maka mengindikasikan telah terjadi heteroskedastisitas. Jika tidak ada pola yang jelas, serta titik-titik menyebar diatas dan dibawah angka 0 pada sumbu Y, maka tidak terjadi heteroskedastisitas (Ghozali, 2001:69).

\section{d. Uji Autokorelasi}

Pengujian asumsi ke-empat dalam model regresi linier klasik adalah uji autokorelasi (autocorrelation). Uji autokorelasi bertujuan untuk menguji apakah dalam suatu model regresi linier ada korelasi antara kesalahan pengganggu pada periode t1 (sebelumnya). Jika terjadi korelasi maka dinamakan ada problem autokerelasi. Uji autokorelasi dapat dilihat dari nilai Durbin Watson. Apabila nilai Durbin Watson berada pada daerah dU sampai 4-dU dapat disimpulkan bahwa model regresi tidak mengandung autokorelasi.

Pengujian terhadap hipotesis dilakukan dengan cara sebagai berikut:

1) Uji F-statistik

Uji digunakan untuk menguji keberartian pengaruh dari seluruh variabel independen secara bersama-sama terhadap variabel dependen.

Hipotesis ini dirumuskan sebagai berikut:

H1 : b1, b2, b3, b4, b5, b6 $\neq 0$

Artinya terdapat pengaruh yang significant secara bersama-sama dari variabel independen (X1 dan X2) terhadap variabel dependen (Y).

Pengambilan keputusan:

Jika probabilitas > 0,05 maka $\mathrm{H} 0$ tidak dapat ditolak (diterima)

Jika probabilitas $<0,05$ maka H0 ditolak dan menerimaHa

Adapun Hipotesisnya:

$\mathrm{HO}=$ tidak ada pengaruh signifikan dari variabel independent secara simultan terhadap variabel dependen.

$\mathrm{Ha}=$ ada pengaruh dari variabel independent secara simultan terhadap variabel dependen.

\section{2) Uji t-statistik}

Uji keberartian koefisien (bi) dilakukan dengan statistik-t (student-t). Hal ini 
dilakukan untuk menguji koefisien regresi secara parsial dari variabel independennya. Adapun hipotesis dilakukan sebagai berikut: $\mathrm{H} 1: \mathrm{bi} \neq 0$

Artinya terdapat pengaruh yang significant dari variabel independen (Xi) terhadap variabel dependen (Y). Pengambilan keputusan:

Jika probabilitas > 0,05 maka H0 tidak dapat ditolak (diterima)

Jika probabilitas $<0,05$ maka H0 ditolak dan menerima $\mathrm{Ha}$

\section{Adapun Hipotesisnya:}

H0 = tidak ada pengaruh signifikan dari variabel independent secara parsial terhadap variabel dependen.

$\mathrm{Ha}=$ ada pengaruh dari variabel independent secara parsial terhadap variabel dependen.

Untuk menguji dominasi variabel independen $(\mathrm{X})$ terhadap variabel dependen (Y) dilakukan dengan melihat pada koefisien beta standar.

Dari hasil regresi berganda menunjukkan seberapa besar variabel dependen bisa dijelaskan oleh variabel bebasnya (Santoso, 2004:167). Dalam penelitian ini menggunakan regresi linier berganda maka masing-masing variabel yaitu kemudahan dalam proses pajak dan pelayanan secara simultan berpengaruh terhadap variabel dependen yaitu kepatuhan wajib pajak orang pribadi yang dinyatakan dengan R2 untuk mengetahui koefisien determinasi atau seberapa besar pengaruh terhadap kepatuhan wajib pajak orang pribadi. Sedangkan untuk mengetahui koefisien determenasi parsial variabel independent terhadap variabel dependen dengan menggunakan $r 2$. Besarnya koefisien determinasi ini adalah 0 sampai dengan 1 . Besarnya koefisien determinasi suatu persaman regresi semakin mendekati 0 , maka semakin kecil pula pengaruh semua variabel independen terhadap variabel dependennya, dan sebaliknya.

\section{Hasil dan Pembahasan}

Data diperoleh dari data primer yang diperoleh dari kuesioner berdasarkan dari hasil perhitungan dengan rumus solvin (Dewinta dan Syafruddin 2012 : 5), diperoleh ukuran sampel sebanyak 100 kuesioner. Kuesioner yang diterima kembali sebanyak 90 kuesioner, sehingga jumlah sampel sebanyak 90 pengamatan.

Dari 100 kuisioner yang disebarkan kepada responden di Kantor Pelayanan Pajak Pratama Bantul, diperoleh 90 kuisioner yang dapat diolah menggunakan SPSS.

Tabel 2

\section{Descriptive Statistics}

\begin{tabular}{lcrrrr}
\hline & & & & & \multicolumn{1}{c}{$\begin{array}{c}\text { Std. } \\
\text { Deviation }\end{array}$} \\
\hline Kepatuhan & 90 & 16 & 25 & 20.80 & 2.260 \\
Kemudahan & 90 & 15 & 40 & 31.11 & 4.578 \\
Pelayanan & 90 & 10 & 39 & 30.44 & 5.583 \\
Valid N & & & & & \\
(listwise) & 90 & & & & \\
\hline
\end{tabular}

Sumber: Data Diolah

Dari tabel diatas dapat dilihat statistik deskriptif menunjukkan bahwa rata-rata (mean) kepatuhan sebesar 20.80 kali dengan standar deviasi sebesar 2.260. Untuk nilai minimum kepatuhan sebesar 16 dan nilai maksimum sebesar 25. Dari tabel juga dapat diketahui bahwa kemudahan mempunyai rata-rata sebesar 31.11 kali dengan standar deviasi sebesar 4.478. Untuk nilai minimum kemudahan sebesar 15 dan nilai maksimum sebesar 40. Sedangkan untuk rata-rata pelayanan sebesar 30.44 dengan standar deviasi sebesar 5.583. Untuk nilai minimum sebesar 10 dan nilai maksimun sebesar 39 . 


\section{Uji Validitas}

Tabel 3

Hasil Pengujian Validitas dan Reliabilitas

\begin{tabular}{|c|c|c|c|c|}
\hline & $\begin{array}{c}\text { Scale } \\
\text { Mean if } \\
\text { Item } \\
\text { Deleted }\end{array}$ & $\begin{array}{c}\text { Scale } \\
\text { Variance } \\
\text { if Item } \\
\text { Deleted }\end{array}$ & $\begin{array}{l}\text { Corrected } \\
\text { Item-Total } \\
\text { Correlation }\end{array}$ & $\begin{array}{l}\text { Cronbach's } \\
\text { Alpha if } \\
\text { Item } \\
\text { Deleted }\end{array}$ \\
\hline butir 1.1 & 97.1 & 136.406 & 0.423 & 0.902 \\
\hline butir 1.2 & 96.94 & 136.682 & 0.428 & 0.902 \\
\hline butir 1.3 & 99.29 & 141.107 & 0.055 & 0.911 \\
\hline butir 1.4 & 97.07 & 135.613 & 0.459 & 0.901 \\
\hline butir 1.5 & 96.87 & 136.724 & 0.457 & 0.901 \\
\hline butir 1.6 & 97 & 136.584 & 0.405 & 0.902 \\
\hline butir 1.7 & 96.98 & 136.382 & 0.341 & 0.903 \\
\hline butir 1.8 & 97.02 & 138.044 & 0.363 & 0.903 \\
\hline butir 1.9 & 99.3 & 144.572 & -0.084 & 0.913 \\
\hline butir 2.1 & 97.17 & 133.107 & 0.493 & 0.901 \\
\hline butir 2.2 & 97.32 & 134.513 & 0.393 & 0.903 \\
\hline butir 2.3 & 97.48 & 134.095 & 0.379 & 0.903 \\
\hline butir 2.4 & 97.19 & 131.885 & 0.589 & 0.899 \\
\hline butir 2.5 & 97.18 & 128.732 & 0.774 & 0.895 \\
\hline butir 2.6 & 97.16 & 131.054 & 0.667 & 0.897 \\
\hline butir 2.7 & 97.59 & 132.11 & 0.514 & 0.9 \\
\hline butir 2.8 & 97.19 & 131.93 & 0.636 & 0.898 \\
\hline butir 2.9 & 97.19 & 134.739 & 0.48 & 0.901 \\
\hline butir3.1 & 97.29 & 129.511 & 0.7 & 0.896 \\
\hline butir 3.2 & 97.23 & 129.462 & 0.702 & 0.896 \\
\hline butir 3.3 & 97.5 & 128.904 & 0.646 & 0.897 \\
\hline butir 3.4 & 97.4 & 131.569 & 0.576 & 0.899 \\
\hline butir 3.5 & 98.22 & 135.501 & 0.264 & 0.907 \\
\hline butir3.6 & 97.5 & 130.635 & 0.617 & 0.898 \\
\hline butir3.7 & 97.34 & 128.161 & 0.752 & 0.895 \\
\hline butir 3.8 & 97.29 & 130.253 & 0.684 & 0.897 \\
\hline butir3.9 & 97.24 & 129.018 & 0.734 & 0.896 \\
\hline
\end{tabular}

\section{Sumber Data Diolah}

Dalam penelitian ini variabel bebas mengandung 3 aspek dengan masing-masing aspek yang terdiri dari 9 pertanyaan. Alat analisis yang digunakan oleh peneliti yaitu menggunakan aplikasi SPSS 16.

Untuk uji validitas, dari data table 4.6 menunjukan kevalidan sebuah butir pertanyaan dan ketidakvalidan butir pertanyaan. Dari data tersebut dapat diperoleh rumus untuk menguji ke validan sebuah butir pertanyaan: df (degree of freedom $)=\mathrm{N}-2$, dan peneliti menggunakan tingkt signifikansi $5 \%$, diperoleh df $=25$, signifikansi $5 \%$ (lihat tabel $\mathrm{r}$ - statistik) didapat nilai $\mathrm{df}=25$, diperoleh $\mathrm{r}$ tabel $=$ 0,380. Dari tabel diatas dapat dilihat bahwa ada 6 butir yang nilai Corrected Item-Total Correlation dibawah 0.380. Jadi dapat disimpulkan bahwa ada 6 butir pertanyaan yang tidak valid. 


\section{Uji Realibilitas}

\begin{tabular}{cr}
\multicolumn{2}{c}{ Tabel $\mathbf{4}$} \\
Reliability Statistics \\
\hline $\begin{array}{c}\text { Cronbach's } \\
\text { Alpha }\end{array}$ \\
\hline \multicolumn{2}{c}{ Nof Items } \\
\hline Sumber Data Diolah
\end{tabular}

Untuk uji reliabilitas digunakan metode Alpha Cronbach's. Koefisien ini merupakan koefisien reliabilitas yang paling sering digunakan karena koefisien ini menggambarkan varians dari item-item baik untuk format benar/ salah. Tabel diatas menunjukkan bahwa $\mathrm{C}$ sebesar 0.904 atau $90.4 \%$. Nilai ini lebih besar dari $70 \%$, sehingga variabel dalam penelitian ini dapat dikatan reliabel.

\section{Uji Asumsi Klasik}

1. Uji Normalitas

Pengujian normalitas data penelitian adalah untuk menguji apakah dalam statistik variabel-variabel penelitian berdistribusi normal atau tidak normal.

\section{Gambar 1}

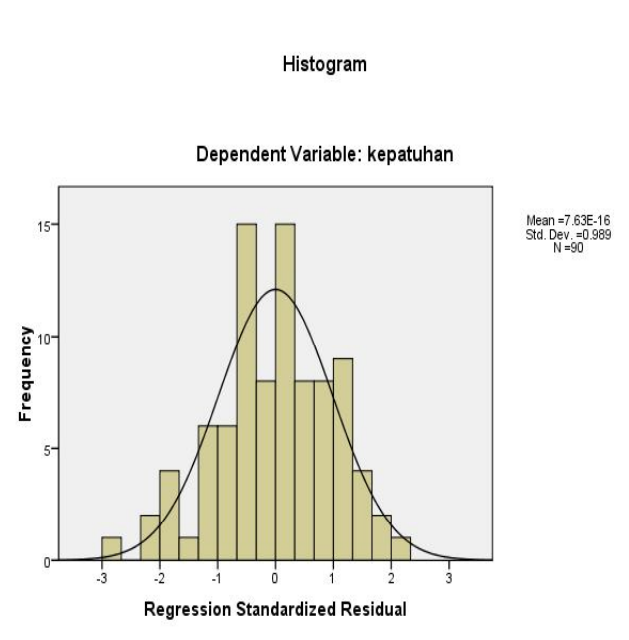

Dari grafik histogram tampak bahwa residual berdistribusi secara normal dan membentuk simetris simetris tidak menceng ke kanan atau ke kiri. Pada grafik normal probability plot titik-titik menyebar berhimpit disekitar diagonal dan hal ini menunjukkan bahwa residual berdistribusi secara normal.

\section{Gambar 2}

Normal P-P Plot of Regression Standardized Residual

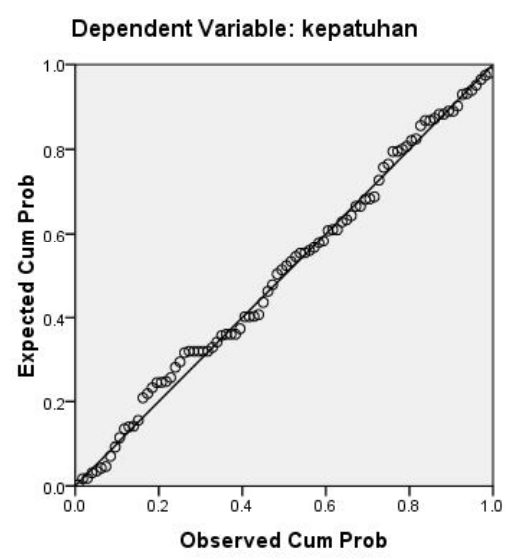

\section{Uji Multikolineritas}

Berdasarkan tabel di bawah ini, tidak terdapat satu variabel yang mempunyai nilai VIF $>10$. Artinya kedua variabel independen tersebut tidak terdapat hubungan multikoloniearitas dan dapat digunkan untuk memprediksi kepatuhan wajib pajak. 


\section{Tabel 5}

Coefficients $^{\mathrm{a}}$

\begin{tabular}{|c|c|c|c|c|c|c|c|c|}
\hline \multirow{2}{*}{\multicolumn{2}{|c|}{ Model }} & \multicolumn{2}{|c|}{$\begin{array}{l}\text { Unstandardized } \\
\text { Coefficients }\end{array}$} & \multirow{2}{*}{$\begin{array}{c}\text { Standardized } \\
\text { Coefficients } \\
\text { Beta }\end{array}$} & \multirow[b]{2}{*}{$\mathrm{t}$} & \multirow[b]{2}{*}{ Sig. } & \multicolumn{2}{|c|}{ Collinearity Statistics } \\
\hline & & B & Std. Error & & & & Tolerance & VIF \\
\hline \multirow[t]{3}{*}{1} & (Constant) & 12.150 & 1.393 & & 8.723 & .000 & & \\
\hline & kemudahan & .209 & .061 & .423 & 3.396 & .001 & .510 & 1.962 \\
\hline & pelayanan & .071 & .050 & .175 & 1.408 & .163 & .510 & 1.962 \\
\hline
\end{tabular}

a. Dependent Variable: kepatuhan

Sumber Data Diolah

\section{Uji Heterokedastisitas}

\section{Gambar 3}

Scatterplot

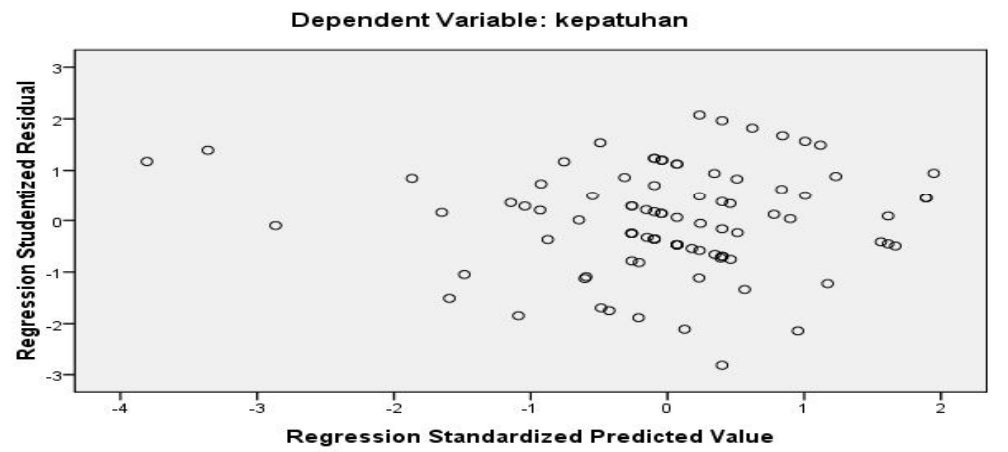

Dari grafik scatterplots terlihat titik- diatas maupun dibawah heteroskedastisitas titik menyebar secara acak (rendum) baik pada model regresi.

\section{Uji Autokorelasi}

Tabel 6

Model Summary ${ }^{b}$

\begin{tabular}{lrrrrr}
\hline Model & R & R Square & $\begin{array}{c}\text { Adjusted R } \\
\text { Square }\end{array}$ & $\begin{array}{l}\text { Std. Error of } \\
\text { the Estimate }\end{array}$ & \multicolumn{2}{c}{$\begin{array}{l}\text { Durbin- } \\
\text { Watson }\end{array}$} \\
\hline 1 & $.559^{\mathrm{a}}$ & .313 & .297 & 1.894 & 2.129 \\
\hline
\end{tabular}

a. Predictors: (Constant), Pelayanan, Kemudahan

b. Dependent Variable: Kepatuhan Sumber Data Diolah

Tampilan output SPSS diatas menunjukkan besarnya nilai Durbin Watson sebesar 2.129. nilai DW menurut tabel dengan $\mathrm{n}=90$ dan $\mathrm{k}=2$ didapat angka $\mathrm{dL}=1.612$ dan $\mathrm{dU}=1.703$. Oleh karena nilai DW 2.129 lebih besar dari batas atas (du) 1.703 dan kurang dari 4- 1.703 (4-du), maka dapat disimpulkan bahwa tidak ada autokorelasi positif atau negatif atau dapat disimpulkan bahwa tidak terdapat autokorelasi.

\section{Analisis Regresi}

Untuk mengetahui pengaruh antara pelayanan dan kemudahan terhadap kepatuhan digunakan persamaan regresi : 


\section{Tabel 7}

Coefficients $^{\mathrm{a}}$

\begin{tabular}{|c|c|c|c|c|c|c|}
\hline \multirow{2}{*}{\multicolumn{2}{|c|}{ Model }} & \multicolumn{2}{|c|}{$\begin{array}{l}\text { Unstandardized } \\
\text { Coefficients }\end{array}$} & \multirow{2}{*}{$\begin{array}{c}\text { Standardized } \\
\text { Coefficients } \\
\text { Beta }\end{array}$} & \multirow[b]{2}{*}{$\mathrm{t}$} & \multirow[b]{2}{*}{ Sig. } \\
\hline & & $\mathrm{B}$ & Std. Error & & & \\
\hline 1 & (Constant) & 12.150 & 1.393 & & 8.723 & .000 \\
\hline & $\begin{array}{l}\text { Kemudaha } \\
\mathrm{n}\end{array}$ & .209 & .061 & .423 & 3.396 & .001 \\
\hline & Pelayanan & .071 & .050 & .175 & 1.408 & .163 \\
\hline
\end{tabular}

a. Dependent Variable: Kepatuhan Sumber Data Diolah

$\mathrm{Y}=12.150+0.209$ Kemudahan +0.071 Pelayanan $+\mathrm{e}$

Dari persamaan regresi linier berganda dapat dijelaskan : Konstanta $(\alpha)$ sebesar 12.150 dan signifikasi sebesar 0.000 artinya

untuk Kemudahan (b2) sebesar 0.209 artinya

\section{Uji Hipotesis}

Penelitian ini menguji hipotesishipotesis dengan menggunakan metode analisis regresi berganda (multiple regression). Metode regresi berganda menghubungkan satu variabel dependen dengan variabel independen dalam satu model prediktif tunggal. Adapun untuk menguji signifikan tidaknya hipotesis tersebut digunakan uji $\mathrm{F}$ dan uji t.

Koefisien determinasi digunakan untuk menguji goodness-fit dari model regresi. Besarnya nilai Adjusted $\mathrm{R}^{2}$ sebesar 0.297 yang berarti variabilitas dependen yang dapat dijelaskan oleh variabilitas variabel independen sebesar 29.7\%. Jadi model kurang baik. Sedangkan sisanya $70.3 \%$ dijelaskan oleh variabel lainnya yang tidak dimasukkan dalam model regresi.

\section{Pembahasan Hasil Penelitian}

Pembahasan dari hasil penelitian sebagai berikut:

(1) Berdasarkan penilaian kelayakan model regresi,nilai parameter simultan $F$ hitung menunjukan angka 19..822 lebih bahwa setiap perubahan kemudahan, maka kepatuhan wajib pajak akan mengalami kenaikan sebesar $0.209 \%$, Koefisien regresi untuk Pelayanan (b1) sebesar 0.071 artinya bahwa setiap perubahan pelayanan, maka kepatuhan wajib pajak akan mengalami kenaikan sebesar $0.071 \%$.

besar dibanding $\mathrm{F}$ tabel sebesar 3.10 dengan nilai signifikan menunjukan angka sebesar 0.000 lebih kecil dibanding dengan nilai signifikan 0.05 . Hal ini menunjukan bahwa model regresi tersebut layak dipakai untuk menganalisis prediksi kepatuhan wajib pajak. (2) Hasil pengujian hipotesis pertama menunjukan bahwa hipotesis pertama diterima. Dari hasil uji t variabel kemudahan dalam proses pembayaran pajak terhadap kepatuhan wajib pajak memiliki nilai $\mathrm{t}$ hitung $=3.396$ dan nilai probabilitas $0.001<$ 0.05 sehingga Ha deterima, Ho ditolak. Hal ini dapat disimpulkan bahwa kemudahan dalam proses pembayaran pajak berpengaruh signifikan positif terhadap kepatuhan wajib pajak. Ini berarti bahwa semakin mudah proses pembayaran pajak akan semakin patuh wajib pajak dalam membayar pajak. Penelitian ini mendukung yang dilakukan fikriningrum (2012) bahwa kemudahan dalam proses pajak berpengaruh signifikan terhadap kepatuhan wajib pajak. (3) Hasil uji $\mathrm{t}$ variabel pelayanan pajak terhadap kepatuhan wajib pajak memiliki nilai $\mathrm{t}$ hitung 1.408 dan nilai probabilitas $0.163>$ 
0.05 sehingga $\mathrm{Ha}$ ditolak sedangkan Ho diterima.hal ini dapat disimpulkan bahwa pelayanan pajak tidak berpengaruh signifikan terhadap kepatuhan wajib pajak.

Temuan ini tidak mendukung dari penelitian Arum (2012) dan fikriningrum (2012), yang menunjukan bahwa pelayanan pajak berpengaruh signifikan terhadap kepatuhan wajib pajak. Disini dijelaskan pelayanan tidak berpengaruh signifikan dapat dimungkinkan karena wajib pajak orang pribadi yang ditemui adalah wajib pajak yang efektif dan berada di Kantor Pelayanan Pajak Pratama Bantul yang tidak memperhatikan pelayanan fiskus hanya memperhatikan bagaimana untuk patuh. (4) Besarnya nilai Adjusted $\mathrm{R}^{2}$ sebesar 0.297 yang berarti variabilitas dependen yang dapat dijelaskan oleh varibilitas variabel independen sebesar 29.7\%. hal ini berarti kemudahan dalam proses pembayaran pajak dan pelayanan pajak secara simultan berpengaruh sebesar $29.7 \%$ terhadap kepatuhan wajib pajak, sedangkan sisanya $70.3 \%$ disebabkan oleh faktor lainnya.

\section{Kesimpulan}

1. Hasil penelitiaan ini menunjukan beberapa faktor yang mempengaruhi kepatuhan wajib pajak orang pribadi di Kantor Pelayanan Pajak Pratama Bantul. Faktor yang diteliti (kemudahan dalam proses pembayaran pajak dan pelayanan pajak), kemudahan dalam proses pembayaran pajak berpengaruh siknifikan dan positif terhadap kepatuhan wajib pajak, sedang pelayanan pajak tidak berpengaruh signifikan terhadap kepatuhan wajib pajak.

2. Besarnya nilai Adjusted $\mathrm{R}^{2}$ sebesar 0.297 yang berarti variabilitas dependen yang dapat dijelaskan oleh variabilitas variabel independent sebesar $29.7 \%$. Hal ini berarti kemudahan dalam proses pembayaran pajak dan pelayanan pajak secara simultan berpengaruh sebesar $29.7 \%$ terhadap kepatuhan wajib pajak, sedang sisanya $70.3 \%$ disebabkan oleh faktor-faktor lainnya jadi wajib pajak dalam membayar pajak atau patuh tidak hanya disebab kan oleh dua faktor saja.

\section{Keterbatasan}

Penelitian ini hanya memfokuskan pada dua variabel yang mempengaruhi kepatuhan wajib pajak, Hanya dilakukan pada satu KPP Pratama sehingga sampelnya hanya 100 respnden, Besarnya nilai Adjusted $\mathrm{R}^{2}$ sebesar 0.297 dan sisanya $70.3 \%$ masih dapat dilakukan penelitian dengan faktor faktor yang lain.

\section{Saran}

Berdasarkan kesimpulan di atas, maka penulis memberikan saran-saran sebagai berikut:

1. Untuk Kantor Pelayanan Pajak

Pratama Bantul

a) Aparat pajak di Kantor Pelayanan Pratama Bantul sebagai pelaksana modernisasi perpajakan harus selalu meningkatkan kinerja mereka dalam memberikan pelayanan prima kepada wajib pajak. b) Penyuluhan perpajakan atau sosialisasi di Kantor Pelayanan Pratama Bantul perlu ditingkatkan untuk menambah Pengetahuaan wajib pajak. c) Prasarana dan sarana penggunaan teknologi dalam rangka peningkatan pelayanan pajak di Kantor Pelayanan Pratama Bantul perlu diperhatikan dan tingkatkan sesuai dengan kebutuhan, dana dan perkembangan zaman. d) Kantor Pelayanan Pratama Bantul perlu memperhatikan keluhan dari masyarakat dan lebih ramah terhadap wajib pajak.

\section{Untuk Penelitian Selanjutnya}

a) Untuk peneliti selanjutnya untuk menambah faktor-faktor variabel yang mempengaruhi kepatuhan wajib pajak orang pribadi. b) Penelitian selanjutnya sebaiknya tidak hanya satu KPP Pratama saja sehingga sampelnya lebih dari 100 responden. c) Untuk penelitian selanjutnya sebaiknya mencari responden wajib pajak tidak hanya yang berada di KPP Pratama. 


\section{DAFTAR PUSTAKA}

Arum, Harjanti Puspa. 2012. Pengaruh Kesadaran Wajib Pajak, Pelayanan Fiskus, dan Saksi Pajak Terhadap Kepatuhan Wajib Pajak Orang Pribadi yang Melakukan Kegiatan Usaha Dan Pekerjaan Bebas.UNDIP.

Budi, Setijo. Analisis Faktor- Faktor Yang Mempengaruhi Pencapaian Target Pajak Se-Kanwil DJP Jawa Timur. STIE Atma Bhakti Surakarta.

Buku Panduan Bendahara. 2010. Kementerian Keuangan Republik Indonesia Direktorat Jenderal Pajak.

Fikriningrum, Winda Kurnia. 2012.Analisis Faktor-faktor yang mempengaruhi Wajib Pajak Orang Pribadi dalam Memenuhi Kewajiban Membayar Pajak.Universitas Diponegoro.

Ghozali, H.Imam.2011. Aplikasi Analisis Mutivariate dengan program IMB SPSS 19.Edisi Kelima
Nuritomo. Pengaruh Peningkatan Penghasialan Tidak Kena Pajak Terhadap Penerimaan Pajak Studi pada KPP Yogyakarta Satu. Universitas Atma Jaya Yogyakarta.

Nurmantu, S. Pengantar Perpajakan. Jakarta. Granit. Kelompok Yayasan Obor Indonesia.

Rindi. 2012. Analisa Tingkat Efektifitas Pajak Daerah Dan Retribusi Daerah Terhadap Pendapatan Daerah Kabupaten Bekasi.Universitas Bina Nusantara Jakarta Barat.

Supadmi, Ni Luh. 2009. Meningkatkan Kepatuhan Wajib Pajak Melalui Kualitas Pelayanan. (http://ejournal.unud.ac.id/abstrak/o k\%20supadmi.pdf)

Waluyo.2011. Perpajakan Indonesia Buku 1. Jakarta.Salemba Empat. 